\title{
Modifikasi Zeolit Alam Ende dengan Garam Logam serta Potensinya Sebagai Katalis Transformasi Glukosa Menjadi 5-Hidroksimetilfurfural (HMF)
}

\author{
Dessy Dwi Septian dan Sri Sugiarti* \\ Departemen Kimia, FMIPA, Institut Pertanian Bogor, Jl. Tanjung Kampus IPB, Dramaga Bogor 16680 telp. \\ (0251) 8624567 \\ * Corresponding author \\ E-mail: srisugiarti@apps.ipb.ac.id
}

DOI: 10.20961/alchemy.15.2.28180.203-218

Received 23 Februari 2019, Accepted 22 Juli 2019, Published 30 September 2019

\begin{abstract}
ABSTRAK
Ketersediaan biomassa yang melimpah berpotensi menjadi bahan baku dalam pembuatan bahan bakar atau senyawa kimia lain. Salah satu senyawa penyusun biomassa, yaitu glukosa, berpotensi diubah menjadi berbagai senyawaan kimia melalui pembentukan senyawa antara furan. Senyawa furan yang menjadi sasaran pada penelitian ini ialah 5-hidroksimetilfurfural (HMF) yang juga memerlukan katalis dalam proses pembentukkannya dari glukosa. Katalis yang digunakan pada penelitian ini adalah katalis heterogen dari zeolit alam Ende yang mengemban lima jenis ion logam dengan konsentrasi $1-3 \%(\mathrm{~b} / \mathrm{v})$. Pengembanan logam dilakukan untuk melihat perbedaan aktivitas katalitik zeolit dengan dan tanpa ion logam, dan sebagai model pemanfaatan zeolit alam yang telah difungsikan sebagai adsorben logam. Pengembanan logam dilakukan dengan metode pertukaran ion sebagai representasi dari proses adsorpsi. Transformasi glukosa menjadi HMF dilakukan menggunakan metode hidrotermal pada suhu $180{ }^{\circ} \mathrm{C}$ dalam pelarut aseton:air (2:1) (v/v) dengan perbandingan substrat:katalis 15:1 (b/b). Zeolit alam Ende dalam bentuk asam dapat membantu transformasi glukosa dengan rendemen $\mathrm{HMF}$ 24,86\%, sementara logam $\mathrm{Cr}$ saja menghasilkan rendemen 44,37\%. Zeolit yang diembankan logam $\mathrm{Cr}$ menghasilkan rendemen 32,78\%, dan semakin banyak logam yang diembankan dalam zeolit menunjukkan penurunan aktivitas katalitiknya. Rendemen HMF tertinggi ditunjukkan pada penggunaan katalis Mn-zeolit dan Ni-zeolit dengan rendemen berturut-turut 35,17\% dan $38,68 \%$.
\end{abstract}

Kata kunci: glukosa, HMF, hidrotermal, pengembanan logam, zeolit alam ende

\section{ABSTRACT}

Modification of Ende Natural Zeolites with Metal Salts and Their Potential as Catalysts for Glucose Transformation To 5-Hydroxymethylfurfural (HMF). The abundance of biomass has the potential to become a raw material in the synthesis of chemical compounds. Glucose, which is contained in biomass, can be converted into various chemical compounds by forming furan intermediate compounds, such as the compound 5-hydroxymethylfurfural (HMF). This transformation can be made possible through the use of heterogeneous catalysts. Our research used natural zeolite from Ende impregnated with five different metals with concentraition $1 \%(\mathrm{w} / \mathrm{v})$ to serve as the heterogeneous catalysts in this transformation process. The transformation of glucose into HMF was carried out using the hydrothermal method at $180{ }^{\circ} \mathrm{C}$ in acetone:water $(2: 1)(\mathrm{v} / \mathrm{v})$ with a substrate:catalyst ratio of 15:1 (w/w). Acidified Ende natural zeolite without metal ions activated the glucose transformation to HMF with a yield of $24.86 \%$, meanwhile Cr-zeolit could support the transformation with a yield of $44,37 \%$. Glucose transformation using $\mathrm{Cr}$-impregnated zeolite revealed a yield of $32,78 \%$. Different concentrations of $\mathrm{Cr}$ adsorbed in the zeolite were tested and showed 
that increased $\mathrm{Cr}$ concentration led to decreased the catalytic activity. The highest HMF yield was obtained with the Mn-zeolit and Ni-zeolit catalysts with yields of $35.17 \%$ and $38.68 \%$, respectively.

Keywords: glucose, hydrothermal, HMF, metal impregnation, ende natural zeolite

\section{PENDAHULUAN}

Sumber daya terbarukan sudah banyak digunakan sebagai agen pengganti bahan bakar fosil seperti minyak bumi. Biomassa, khususnya lignoselulosa yang terdiri dari 40 50\% selulosa, berpotensi sebagai bahan awal pembuatan bahan bakar maupun bahan kimia karena keberadaannya yang melimpah, murah, dan mudah didapatkan. Selulosa dapat dimanfaatkan sebagai sumber karbon dalam pembuatan senyawa-senyawa penting melalui pembentukan senyawa antara furan (Guerriro et al., 2016). Senyawa 5hidroksimetilfurfural (HMF) merupakan turunan furan multifungsi yang dapat menjadi senyawa antara dalam pembuatan polimer, bahan bakar, bahan kimia murni, dan turunan senyawa organik lainnya (Tong et al., 2010).

HMF dapat disintesis melalui proses dehidrasi 3 molekul air dari fruktosa (Rosatella et al., 2011). Penggunaan fruktosa sebagai bahan awal produksi HMF memiliki kelebihan dari segi rendemen yang tinggi, namun ketersediaan fruktosa sebagai bahan baku masih sedikit dan harganya masih terbilang mahal, sehingga glukosa dapat dijadikan alternatif dalam produksi HMF (Zhou et al., 2016). Proses dehidrasi fruktosa dalam sintesis HMF sendiri biasanya dibantu menggunakan katalis homogen asam seperti $\mathrm{HCl}$ (Nikolla et al., 2011; Huang and Fu, 2013). Namun, penggunaan katalis homogen asam memiliki beberapa kekurangan, seperti pemisahan yang sulit dan menyebabkan korosi pada alat (Villa et al., 2013). Selain itu, katalis asam tersebut biasanya lebih berperan dalam proses dehidrasi menjadi HMF, sedangkan untuk isomerisasi glukosa menjadi fruktosa dibutuhkan katalis asam maupun basa Lewis (Yu and Tsang, 2017). Katalis bifungsi diperlukan dalam sintesis 'one pot' HMF sehingga proses berjalan lebih efisien. Zeolit adalah katalis asam bifungsional karena memiliki dua situs aktif, yakni situs asam Brønsted dan asam Lewis.

Zeolit merupakan mineral aluminosilikat yang memiliki struktur berpori yang unik sehingga dapat digunakan sebagai adsorben, penukar ion, hingga sebagai katalis. Pori-pori pada zeolit juga dapat menyebabkan reaksi menjadi lebih spesifik (Jae et al., 2011). Zeolit alam merupakan salah satu komoditas yang banyak terdapat di Indonesia, namun masih kurang dalam pemanfaatannya (Ngapa et al., 2016). Sejauh ini, zeolit lebih banyak dimanfaatkan sebagai adsorben logam berat (Salam et al., 2011; Uddin, 2017). Namun, 
permasalahan yang kemudian timbul adalah perlakuan yang harus dilakukan terhadap logam berat yang telah diadsorpsi. Oleh karena itu, modifikasi berupa pengembanan logam dilakukan sebagai representatif zeolit yang telah mengadsorpsi logam. Selain itu, modifikasi juga ditujukan untuk memperbesar situs asam Lewis dari zeolit yang berguna pada tahap isomerisasi glukosa menjadi fruktosa.

Proses dehidrasi tiga molekul air dari fruktosa menjadi HMF memerlukan suatu katalis asam Brønsted yang menjadi acuan dilakukan modifikasi membentuk H-zeolit (Yu and Tsang 2017). Proses pembentukan H-zeolit tidak dapat dilakukan secara langsung karena ketidakstabilan interaksi ion $\mathrm{H}^{+}$dengan $\mathrm{O}$ pada kerangka zeolit (Warner et al., 2017). Hal tersebut membuat proses pembentukannya dilakukan melalui pertukaran ion antara $\mathrm{Na}$ zeolit dan ion amonium $\left(\mathrm{NH}_{4}{ }^{+}\right)$. Proses pemanasan dan kalsinasi yang dilakukan setelah proses pertukaran ion bertujuan menghilangkan gas $\mathrm{NH}_{3}$ dan air yang masih berada pada pori zeolit sehingga menyisakan ion $\mathrm{H}^{+}$saja yang berinteraksi dengan atom $\mathrm{O}$ zeolit (Warner et al., 2017). Pembentukan H-zeolit dari $\mathrm{NH}_{4}$-zeolit menggunakan bantuan suhu dapat dilihat pada Gambar 1.

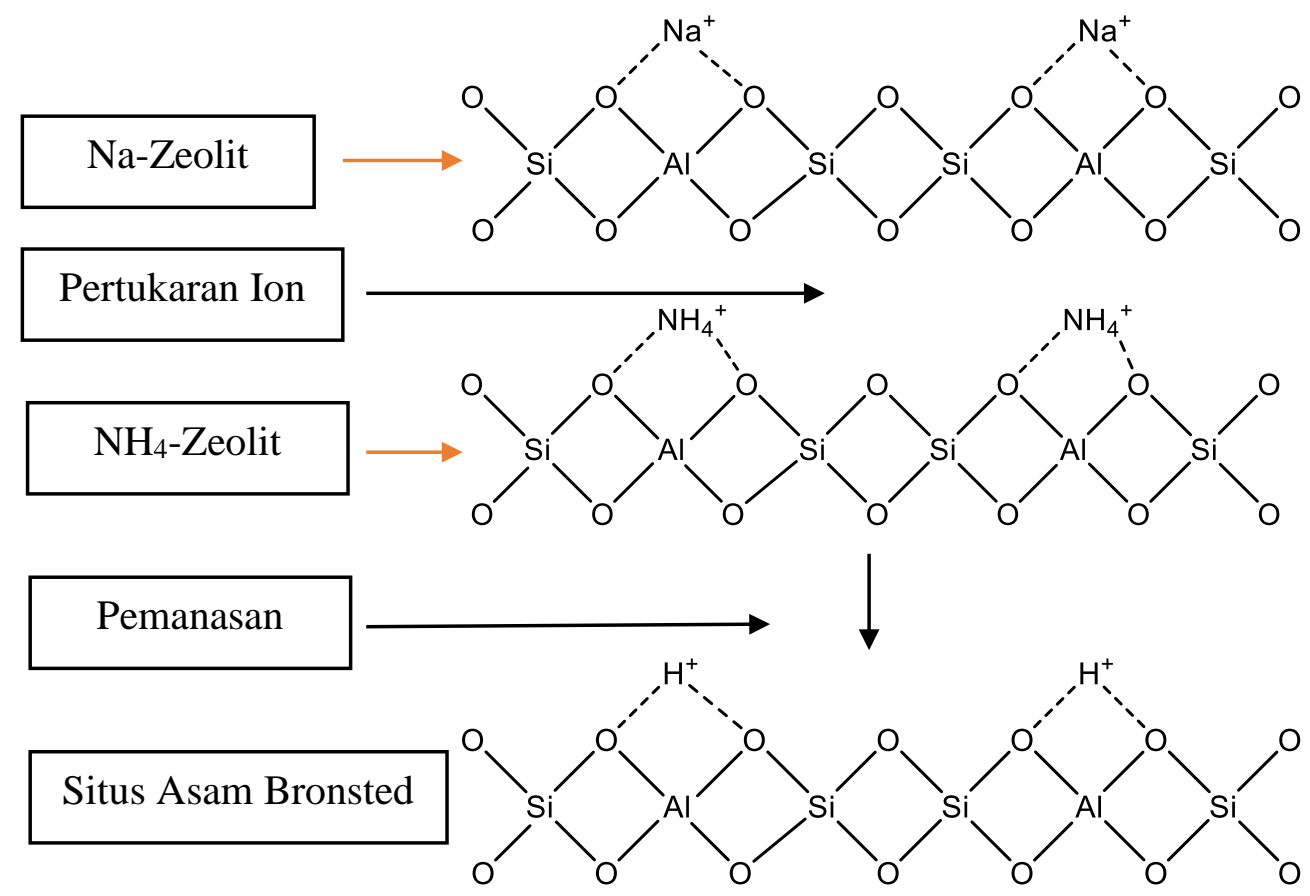

Gambar 1. Skema pembentukan H-zeolit (Hattori and Onno, 2015)

Berdasarkan studi literatur tersebut, modifikasi zeolit alam menjadi bentuk asamnya dan diembankannya logam perlu dilakukan untuk menjadikan zeolit sebagai katalis bifungsi untuk transformasi glukosa menjadi HMF dan meningkatkan fungsi zeolit alam 
Ende, NTT. Studi ini juga dapat dijadikan rujukan untuk memanfaatkan zeolit yang telah digunakan sebagai adsorben logam.

\section{METODE PENELITIAN}

Metode bahan yang digunakan antara lain adalah zeolit alam Ende-NTT, aseton (p.a Merck), metanol (p.a Merck), metanol (LC Merck), $\mathrm{MnSO}_{4} \cdot \mathrm{H}_{2} \mathrm{O}$ (Merck), $\mathrm{CrCl}_{3} \cdot 6 \mathrm{H}_{2} \mathrm{O}$ (Merck), $\mathrm{NiSO}_{4} \cdot 6 \mathrm{H}_{2} \mathrm{O}$ (Merck), $\mathrm{CuSO}_{4} \cdot 5 \mathrm{H}_{2} \mathrm{O}$ (Merck), $\mathrm{CoCl}_{2} \cdot 6 \mathrm{H}_{2} \mathrm{O}$ (Merck), $\mathrm{NaOH}$ (Merck), $\mathrm{NH}_{4} \mathrm{Cl}$ (Merck), glukosa (Merck), standar 5-hidroksimetilfurfural (HMF) (Sigma Aldrich), akuades, dan indikator $\mathrm{pH}$ universal.

Alat yang digunakan adalah High Performance Liquid Chromatography (HPLC) type Shimadzu Prominence CTO-20A, Fourier Transform Infrared Spectrophotometer (FTIR) type Shimadzu 8400S, Atomic Absorption Spectrophotometer (AAS) Shimadzu AA-70, X-ray Diffraction (XRD) type PANAnalytical, Furnace Thermolyte 47900, dan Oven type Sanyo MOV-212.

\section{Aktivasi Zeolit Alam}

Aktivasi zeolit mengacu pada penelitian Ngapa et al. (2016), zeolit Ende-NTT mula-mula diayak dengan ayakan 100 mesh. Aktivasi kimia dilakukan dengan menggunakan $\mathrm{HCl} 1 \mathrm{M}$ dan $\mathrm{NaOH} 1 \mathrm{M}$ yang masing-masing dicampurkan dengan $100 \mathrm{~g}$ zeolit alam dibantu pengadukan dengan pengaduk magnet selama 3 jam. Zeolit yang telah diaktivasi kemudian dicuci dengan akuades hingga $\mathrm{pH}$ netral dan dikeringkan dalam oven pada suhu $110{ }^{\circ} \mathrm{C}$. Zeolit hasil aktivasi direndam selama 24 jam dengan $\mathrm{NaOH} 2 \mathrm{M}$. Sampel kemudian disaring dan dicuci dengan akuades hingga $\mathrm{pH}$ netral. Zeolit yang telah netral dikeringkan dalam oven pada suhu $130{ }^{\circ} \mathrm{C}$ dan didapatkanlah Na-zeolit sesuai prosedur yang telah dilaporkan Nurhadi et al. (2001).

\section{Transformasi Na-zeolit menjadi H-zeolit}

Zeolit alam teraktivasi direndam dengan $\mathrm{NaOH} 2 \mathrm{M}$ selama 24 jam dan diaduk selama 3 jam menggunakan pengaduk magnet. Kemudian, sampel dicuci dengan akuabides hingga $\mathrm{pH}$ netral. Setelah itu, zeolit dikeringkan di dalam oven pada suhu $105{ }^{\circ} \mathrm{C}$ selama 3 jam untuk memperoleh Na-zeolit alam. Na-zeolit alam dikonversi menjadi H-zeolit untuk meningkatkan keasaman dengan metode pertukaran ion $\mathrm{Na}^{+}$dengan $\mathrm{NH}_{4}{ }^{+}$menggunakan larutan $\mathrm{NH}_{4} \mathrm{Cl} 1 \mathrm{M}$. Na-zeolit direndam dalam $\mathrm{NH}_{4} \mathrm{Cl} 1 \mathrm{M}$ dan diaduk selama 24 jam. Rasio Na-zeolit dengan $\mathrm{NH}_{4} \mathrm{Cl}$ adalah 1:5. Setelah itu, zeolit yang direndam $\mathrm{NH}_{4} \mathrm{Cl}$ 
dikeringkan dan dikalsinasi pada suhu $500{ }^{\circ} \mathrm{C}$ untuk menghilangkan $\mathrm{NH}_{3}$ dan agar terbentuk H-zeolit.

Keberhasilan pengubahan menjadi H-zeolit ditentukan dengan analisis keasaman zeolit menggunakan metode gravimetri dengan memanfaatkan adsorpsi piridin. Krus porselen dipanaskan dalam oven pada suhu $120{ }^{\circ} \mathrm{C}$, didinginkan, dan ditimbang bobotnya. Masing-masing katalis ditimbang bobotnya seberat 0,5 $\mathrm{g}$ dan dimasukkan ke dalam krus porselen. Krus porselen yang telah berisi katalis dimasukkan dalam desikator yang telah berisikan $15 \mathrm{~mL}$ piridin selama 24 jam. Setelah 24 jam, katalis yang telah mengadsorpsi piridin ditimbang bobotnya dan ditentukan keasamannya dengan rumus di bawah. Derajat kristalinitas zeolit alam hingga H-zeolit ditentukan berdasarkan pencocokkan manual intensitas puncak pada $2 \theta$ hasil XRD sampel dengan JCPDS mordenit (JCPDS 06-0239) juga klinoptilolit (JCPDS 47-1870) dan dibagi dengan total intensitas sampel.

\section{Keasaman katalis $(\mathrm{mmol} / \mathrm{g})=\frac{\text { Bobot piridin }(\mathrm{g})}{\mathrm{BM} \text { piridin }\left(\frac{\mathrm{g}}{\mathrm{mmol}}\right) \times \text { bobot katalis }(\mathrm{g})}$}

Pengembanan Logam Cr, Mn, Co, Ni, dan Cu dalam Zeolit

Pembuatan katalis heterogen $\mathrm{Cr}$-zeolit dilakukan menggunakan metode pertukaran ion dengan dicampurkannya $5 \mathrm{~g}$ H-zeolit aktivasi asam ke dalam $1 \%$ (b/v) $\mathrm{CrCl}_{3} \cdot 6 \mathrm{H}_{2} \mathrm{O}$. Campuran kemudian diaduk dengan pengaduk magnetik selama semalam pada suhu ruang, disaring, dikeringkan dalam oven pada suhu $105{ }^{\circ} \mathrm{C}$, dan dikalsinasi pada suhu $500{ }^{\circ} \mathrm{C}$ selama 2 jam (Pierella et al., 2008). Efisiensi pengembanan ditentukan dengan rumus di bawah ini dengan pengukuran konsentrasi menggunakan AAS. Selain itu, zeolit yang telah diemban logam juga dianalisa dengan XRD. Pengembanan Cr dengan konsentrasi 2 dan $3 \%(\mathrm{~b} / \mathrm{v})$ dilakukan dengan cara yang sama, hanya saja konsentrasi larutan garam logam yang digunakan berbeda. Pengembanan logam lainnya juga dilakukan dengan cara yang sama dengan menggunakan garam logam $\mathrm{MnSO}_{4} \cdot \mathrm{H}_{2} \mathrm{O}, \mathrm{NiSO}_{4} \cdot 6 \mathrm{H}_{2} \mathrm{O}, \mathrm{CuSO}_{4} \cdot 5 \mathrm{H}_{2} \mathrm{O}$, dan $\mathrm{CoCl}_{2} \cdot 6 \mathrm{H}_{2} \mathrm{O}$ dengan konsentrasi $1 \%(\mathrm{~b} / \mathrm{v})$.

$$
\text { Efisiensi pengembanan }(\%)=\frac{\text { massa logam teremban }(\mathrm{g})}{\text { massa logam awal }(\mathrm{g})} \times 100 \%
$$

\section{Transformasi Glukosa menjadi HMF}

Proses konversi HMF dari glukosa dilakukan secara hidrotermal di dalam autoklaf. Sebanyak $150 \mathrm{mg}$ glukosa dan $10 \mathrm{mg}$ katalis dimasukkan ke dalam autoklaf (Aylak et al., 2016), kemudian $10 \mathrm{~mL}$ air dan $20 \mathrm{~mL}$ aseton ditambahkan, setelah itu autoklaf dipanaskan di dalam oven pada suhu $180{ }^{\circ} \mathrm{C}$ dengan waktu transformasi yang berbeda untuk setiap logam. Pemilihan waktu transformasi didasarkan munculnya warna khas dari 
HMF yaitu kuning kecoklatan. Kemunculan warna hitam menunjukkan telah terjadi oksidasi lanjutan dengan kemungkinan besar akan terbentuk asam levulinat atau karamelisasi sehingga waktu reaksi berbeda. Setelah reaksi selesai, autoklaf didinginkan di suhu ruang kemudian larutan hasil konversi glukosa disimpan di dalam lemari pendingin suhu $4{ }^{\circ} \mathrm{C}$. Hasil konversi glukosa menjadi HMF dicirikan menggunakan HPLC dengan fase gerak metanol dan air (nisbah 5:95) (Zhou et al., 2016). Standar HMF digunakan sebagai standar eksternal. Kromatogram HMF hasil sintesis dan standar dibandingkan dan digunakan untuk menghitung rendemen HMF.

$$
\text { Rendemen HMF }(\%)=\frac{\text { mol HMF }}{\text { mol glukosa }} \times 100 \%
$$

\section{HASIL DAN PEMBAHASAN}

Pencirian zeolit alam sebelum aktivasi dengan XRD menunjukkan bahwa zeolit alam Ende merupakan campuran zeolit jenis klinoptilolit dan mordenit seperti yang telah dilaporkan Ngapa et al. (2016) (Gambar 2). Hal tersebut terkonfirmasi melalui puncakpuncak pada sudut $2 \theta$ yang sesuai dengan data JCPDS (Joint Committee of Powder Diffraction Standards) untuk zeolit tipe klinoptilolit (JCPDS 47-1870) dan mordenit (JCPDS 06-0239). Intensitas puncak tertinggi dari difraktogram zeolit untuk tipe mordenit ialah pada $2 \theta 25,55^{\circ}, 26,58^{\circ}$, dan $27,62^{\circ}$, sedangkan untuk jenis klinoptilolit ditandai dengan puncak pada $2 \theta 13,09^{\circ}, 19,07^{\circ}$, dan $22,17^{\circ}$. Tipe zeolit ini memang diharapkan karena mampu mengatalisis lebih baik dari H-zeolit jenis lainnya karena ukuran porinya yang besar (Li et al., 2014).

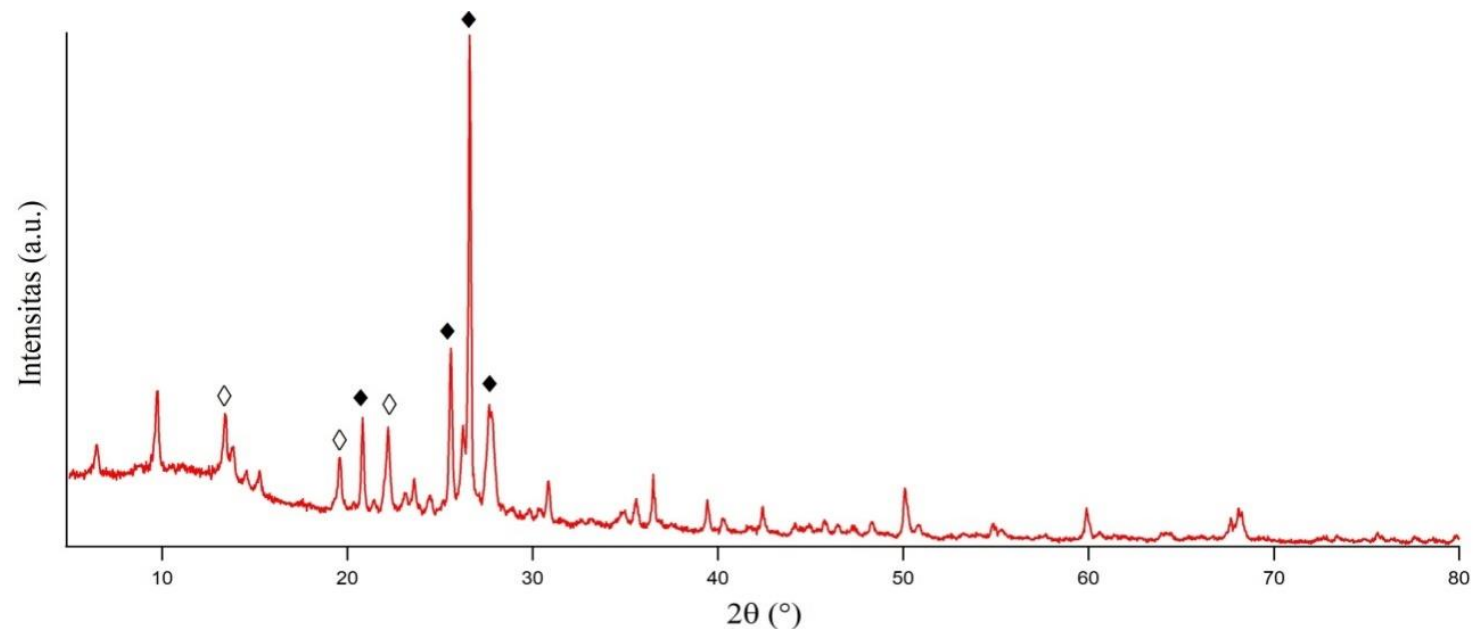

Gambar 2. Difraktogram zeolit alam Ende-NTT sebelum aktivasi dengan $(\diamond)$ tipe klinoptilolit dan ( $\diamond)$ tipe mordenit 
Zeolit alam Ende-NTT diaktivasi dengan dua cara, yaitu dengan asam $(\mathrm{HCl})$ dan basa $(\mathrm{NaOH})$. Proses aktivasi menggunakan asam (ZAA) maupun basa (ZAB) diketahui tidak terlalu mempengaruhi difraktogram yang dihasilkan, begitu pula pada modifikasi menjadi bentuk Na-zeolit dan H-zeolit (Gambar 3). Proses aktivasi dan modifikasi pada zeolit hanya sedikit menggeser puncak yang dihasilkan, namun berpengaruh kepada naiknya derajat kristalinitas yang diperoleh dari perbandingan puncak kristalin pada data XRD dengan JCPDS mordenit dan klinoptilolit (Tabel 1).
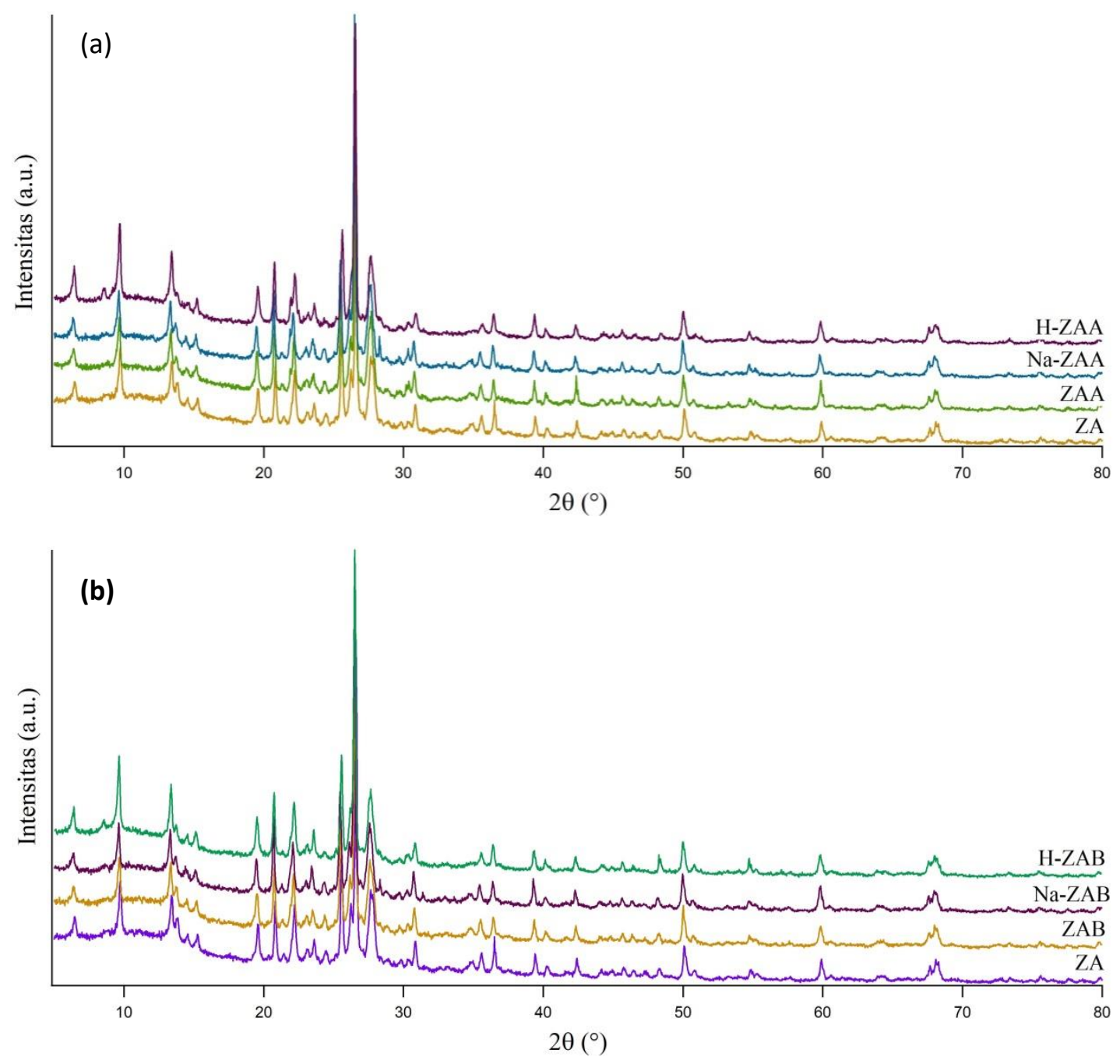

Gambar 3. Difraktogram zeolit Ende aktivasi asam (a) dan basa (b)

Zeolit dengan perlakuan asam menunjukkan derajat kristalinitas yang lebih tinggi dibandingkan basa (Tabel 1). Hal tersebut disebabkan perlakuan asam dapat melarutkan pengotor logam pada zeolit. Namun untuk zeolit tertentu, dealuminasi dapat menyebabkan runtuhnya struktur zeolit yang justru menurunkan kristalinitasnya (Silaghi et al., 2016). Modifikasi menjadi Na-zeolit pada aktivasi asam juga meningkatkan kristalinitas zeolit akibat adanya penataan ulang pada struktur zeolit. Peningkatan kristalinitas juga 
ditunjukkan oleh zeolit aktivasi basa karena perlakuan basa juga dapat membersihkan pengotor dan membantu pembentukan sistem mesopori zeolit (Octaviani et al., 2013). Hasil keasaman zeolit alam dan H-zeolit dapat dilihat pada Tabel 2. Kenaikan keasaman H-zeolit sebanyak 57\% membuktikan bertambahnya situs-situs asam Brønsted dan Lewis pada zeolit (Trisunaryanti, 2016). Hal ini disebabkan piridin dapat berinteraksi dengan asam Lewis maupun Brønsted pada zeolit, baik secara koordinasi maupun kovalen biasa. Kenaikan situs asam Brønsted maupun Lewis pada zeolit akan sangat membantu dalam transformasi glukosa menjadi HMF kedepannya.

Tabel 1. Data kristalinitas zeolit alam Ende-NTT

\begin{tabular}{lc}
\hline Sampel & $\begin{array}{c}\text { Derajat } \\
\text { kristalinitas }(\%)\end{array}$ \\
\hline Zeolit alam & 54,64 \\
Zeolit aktivasi asam & 62,65 \\
Na-zeolit asam & 66,38 \\
H-zeolit asam & 67,79 \\
Zeolit aktivasi basa & 60,92 \\
Na-zeolit basa & 61,65 \\
H-zeolit basa & 63,34 \\
\hline
\end{tabular}

Tabel 2. Keasaman katalis

\begin{tabular}{lc}
\hline Sampel & $\begin{array}{c}\text { Keasaman katalis } \\
(\mathrm{mmol} / \mathrm{g})\end{array}$ \\
\hline Zeolit alam & 0,161 \\
H-zeolit & 0,283 \\
\hline
\end{tabular}

Terembannya logam ke dalam zeolit ditandai dengan munculnya puncak kristalin baru pada difraktogram XRD bila dibandingkan dengan difraktogram H-zeolit (Gambar 4). Puncak-puncak tersebut merupakan puncak logam oksida yang terbentuk akibat proses kalsinasi saat pengembanan. Puncak $\mathrm{Cr}_{2} \mathrm{O}_{3}$ terlihat pada $2 \theta 55^{\circ}$ (JCPDS no. 38-1479), puncak $\mathrm{NiO}$ pada $2 \theta 37,06^{\circ}$ (JCPDS no. 73-1519), dan puncak $\mathrm{MnO}_{2}$ pada $2 \theta 37,5^{\circ}$ (JCPDS no. 44-0141). Puncak Cu oksida yang bisa terlihat pada $2038^{\circ}$ (JCPDS 05-0661) dan Co oksida pada $2 \theta$ 35,8 dan 58,2 $2^{\circ}$ (JCPDS 43-1003) tidak terlihat karena konsentrasi logam teremban yang sedikit (Gambar 5). Derajat kristalinitas juga dapat berubah akibat diembankannya logam. Menurut Covarrubias et al. (2011), derajat kristalinitas juga dipengaruhi oleh kondisi kalsinasi yang diterima sampel. Hal ini membuat derajat kristalinitas zeolit modifikasi yang mengalami dua kali kalsinasi lebih tinggi dibandingkan 
H-zeolit yang hanya sekali kalsinasi saja (Gambar 6). Penyimpangan pada pengembanan nikel terjadi karena justru menurunkan derajat kristalinitasnya. Hal ini mungkin disebabkan oleh proses pengembanan logam untuk Ni yang juga menggunakan suhu tinggi, sehingga diduga struktur zeolit terpengaruh oleh dua proses pemanasan tersebut yakni kalsinasi dan pemanasan saat pengembanan nikel.

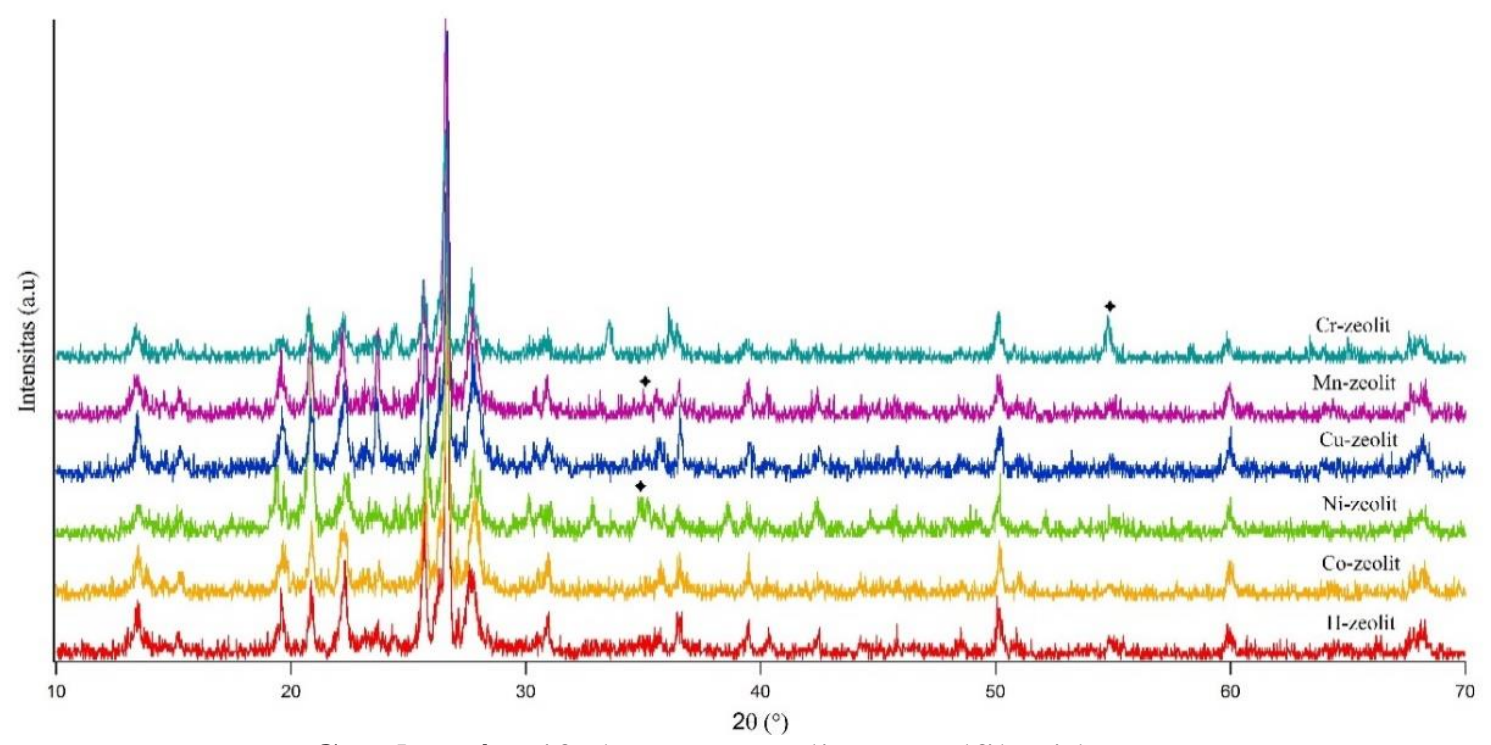

Gambar 4. Difraktogram zeolit termodfikasi logam

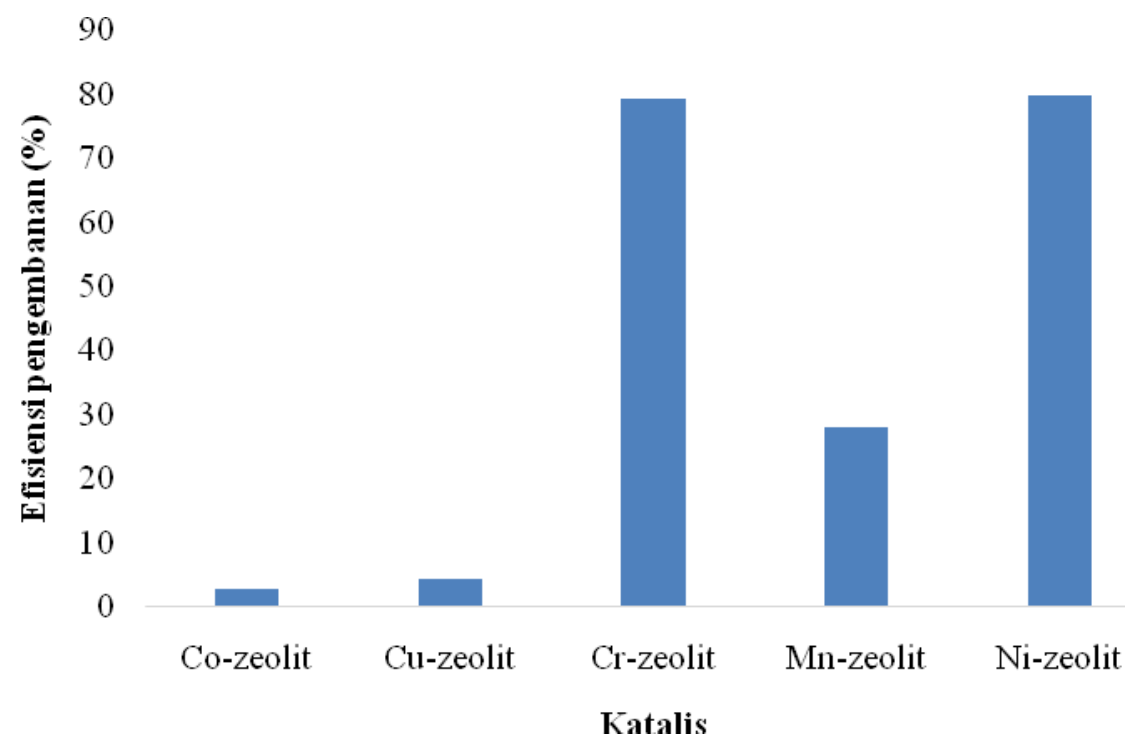

Gambar 5. Efisiensi pengembanan zeolit 


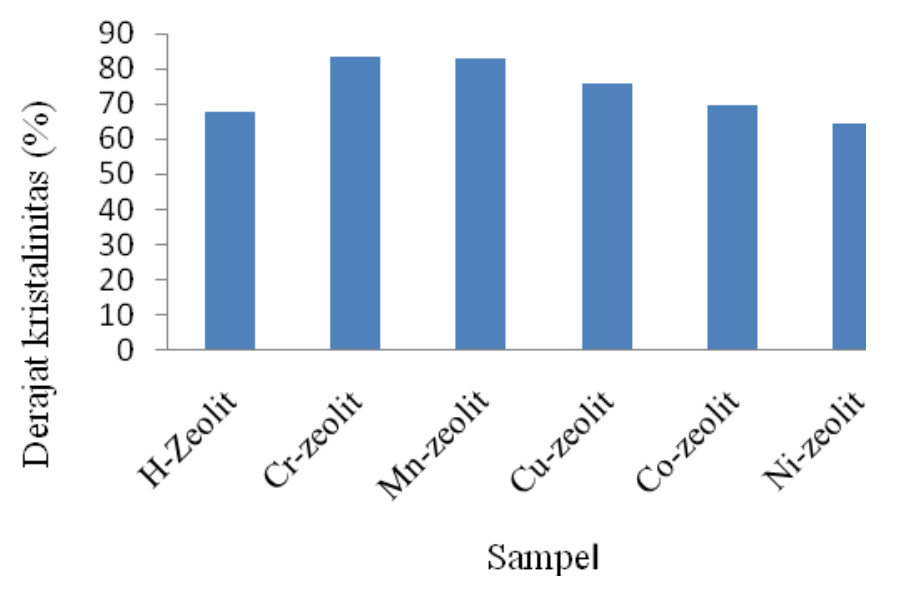

Gambar 6. Derajat kristalinitas zeolit termodifikasi logam

Transformasi glukosa menjadi HMF terdiri atas dua tahapan reaksi, yakni isomerisasi glukosa menjadi fruktosa dan dehidrasi tiga molekul air menjadi HMF (Eminov et al. 2016). Transformasi ini berhasil dilakukan dengan didapatkannya puncak pada kromatogram yang waktu retensinya mirip dengan standar, yakni pada waktu 7,6 menit (Gambar 7). Sementara itu, puncak untuk substrat glukosa mengalami pergeseran pada waktu retensi 7,9 menit. Perbedaan waktu retensi yang dekat ini menunjukkan telah terjadinya transformasi pada glukosa menjadi senyawa lain yang strukturnya tidak jauh berbeda dan terkonfirmasi sebagai HMF. Katalis zeolit alam memiliki aktivitas walaupun sangat rendah, karena tidak tersedianya situs asam Brønsted untuk membantu proses dehidrasi. H-zeolit dari hasil modifikasi zeolit alam Ende memiliki potensi untuk menghasilkan HMF (Tabel 3) karena zeolit sendiri memang sudah memiliki situs asam Brønsted dari pengubahan bentuk menjadi H-zeolit dan asam Lewis pada atom Si maupun Al pada kerangka zeolit.

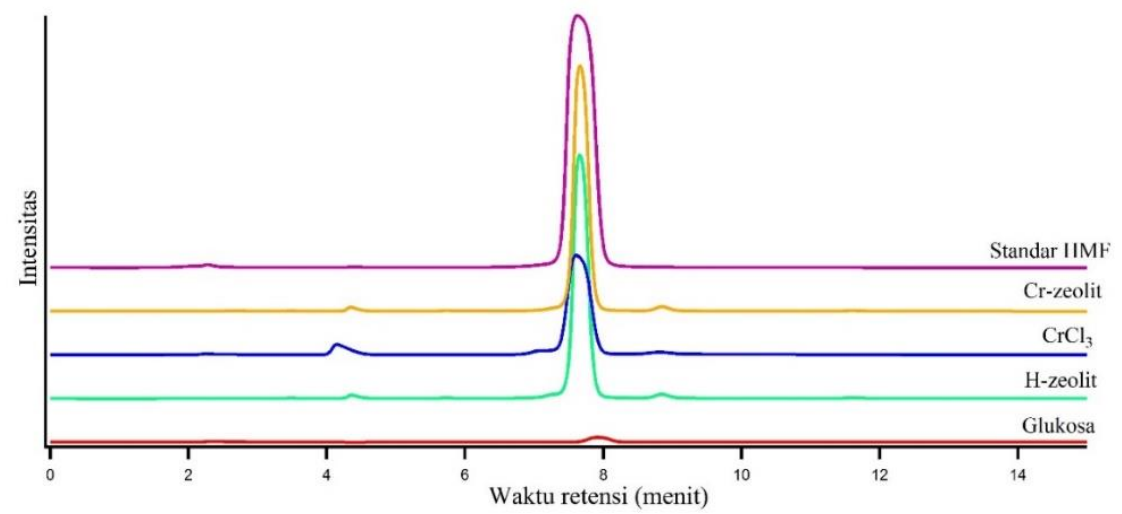

Gambar 7. Kromatogram HMF dengan katalis homogen dan heterogen. 
Tabel 3 Rendemen HMF menggunakan katalis homogen dan heterogen

\begin{tabular}{lccc}
\hline Katalis & $\begin{array}{c}\text { Waktu } \\
(\mathrm{Jam})\end{array}$ & $\begin{array}{c}\text { Suhu } \\
\left({ }^{\circ} \mathrm{C}\right)\end{array}$ & $\begin{array}{c}\text { Rendemen } \\
(\%)\end{array}$ \\
\hline Zeolit Alam & 6,0 & 180 & 3,20 \\
$\mathrm{H}-z e o l i t$ & 6,0 & 180 & 24,86 \\
$\mathrm{CrCl}_{3} \cdot 6 \mathrm{H}_{2} \mathrm{O}$ & 1,5 & 180 & 44,37 \\
$\mathrm{Cr}^{-z e o l i t}$ & 6,0 & 180 & 32,78 \\
\hline
\end{tabular}

Situs asam Lewis sendiri dapat membantu proses isomerisasi glukosa menjadi fruktosa. Asam Lewis memfasilitasi pembukaan cincin dari glukosa yang kemudian akan membentuk kompleks dengan glukosa asiklik pada gugus hidroksilnya ( $\mathrm{C} 1$ dan $\mathrm{C} 2$ ). Adanya orbital yang kosong pada asam Lewis membuat proses transfer elektron dari O1 ke $\mathrm{O} 2$ dan transfer proton dari C2 ke C1 lebih mudah dilakukan (Roman-Leshkov et al., 2010). Transfer proton yang terjadi merupakan titik akhir isomerisasi glukosa menjadi fruktosa (Gambar 8).
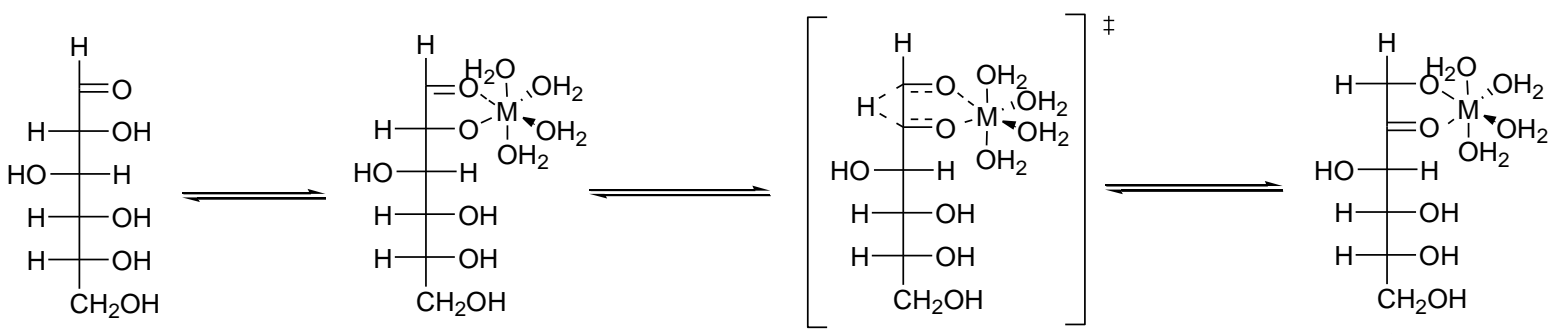

Glukosa

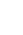


energi aktivasi disebabkan dehidrasi molekul air pertama pada glukosa bukan terjadi pada gugus hidroksi C1 (hemiasetal), melainkan pada gugus hidroksi C2 yang kurang reaktif. Setelah itu, dehidrasi pada C3 terjadi dan diikuti penyerangan C2 oleh O1 untuk membentuk intermediet furan aldehida (Qian, 2011).

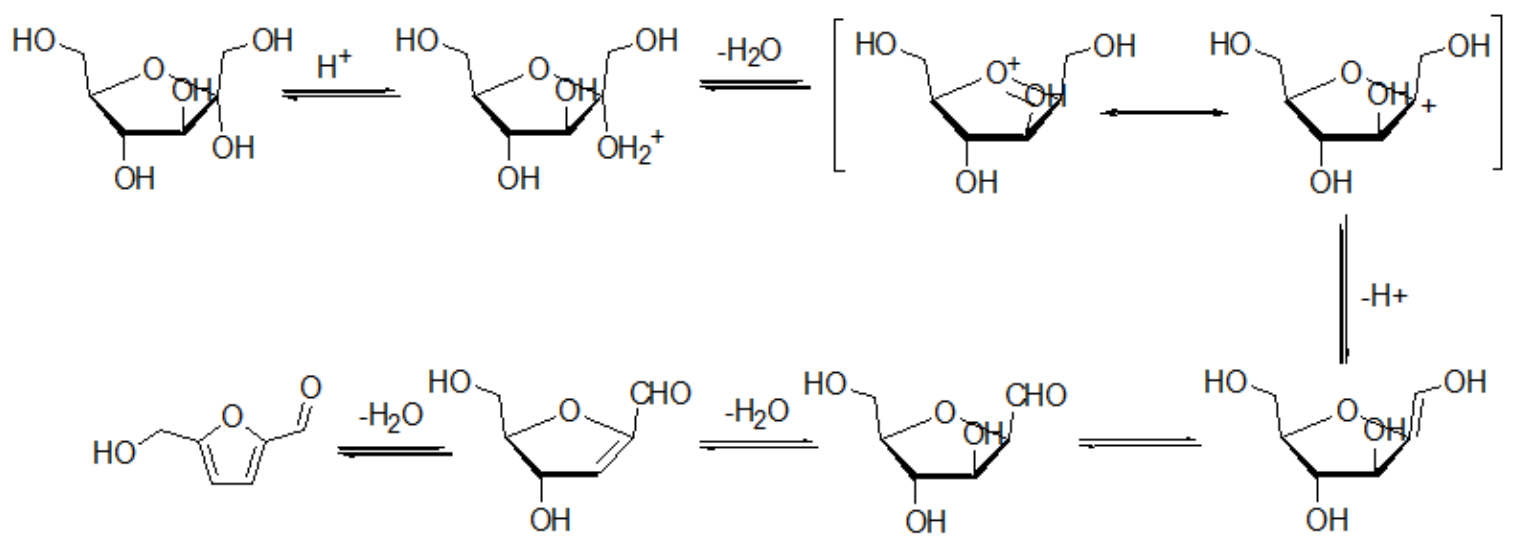

Gambar 9. Reaksi dehidrasi fruktosa menjadi HMF (Assary et al., 2012)

Aktivitas katalitik H-zeolit dan zeolit alam dapat dikatakan jauh lebih rendah dibandingkan katalis homogen garam kromium. Putten et al. (2013) juga menyatakan bahwa katalis $\mathrm{Cr}$, baik bilangan oksidasi 2 maupun 3, dapat menghasilkan rendemen mencapai $80 \%$ dengan bahan awal fruktosa dan pelarut ionik. Walaupun dalam penelitian ini garam kromium juga memiliki performa yang baik dalam mengatalisis transformasi glukosa menjadi HMF hanya dalam waktu yang singkat (1,5 jam), namun jenis katalis homogen seperti ini menyulitkan dalam proses pemisahan katalis pada akhir reaksi. Hal menarik justru ditunjukkan pada aktivitas $\mathrm{Cr}$ setelah diembankan ke dalam zeolit. Aktivitas katalitik Cr justru menunjukkan hasil yang tidak sinergis dengan aktivitas katalitik zeolit. Hal ini mungkin disebabkan masuknya $\mathrm{Cr}$ ke pori zeolit menyebabkan $\mathrm{Cr}$ kurang dapat terakses oleh substrat sehingga proses isomerisasi glukosa menjadi fruktosa tidak terkatalisis maksimal walaupun dengan waktu reaksi yang lebih lama.

Banyaknya logam yang diembankan juga dapat mempengaruhi aktivitas katalitiknya. Aktivitas katalitik zeolit yang diembankan logam kromium menunjukkan penurunan aktivitas. Hal ini dapat terjadi karena dengan lebih banyaknya $\mathrm{Cr}$ yang masuk ke dalam zeolit menandakan pertukaran ion antara ion $\mathrm{H}^{+}$dengan $\mathrm{Cr}^{3+}$ semakin banyak, sehingga proses dehidrasi yang seharusnya memanfaatkan keberadaan situs asam Brønsted kurang maksimal (Tabel 4). 
Tabel 4. Rendemen HMF berdasarkan konsentrasi logam pada katalis

\begin{tabular}{lcc}
\hline Katalis & $\begin{array}{c}\text { Waktu } \\
(\mathrm{Jam})\end{array}$ & $\begin{array}{c}\text { Rendemen } \\
(\%)\end{array}$ \\
\hline Cr-zeolit 1\% & 2 & 7,89 \\
& 6 & 32,78 \\
Cr-zeolit 2\% & 2 & 5,25 \\
& 6 & 24,64 \\
Cr-zeolit 3\% & 6 & 22,53 \\
\hline
\end{tabular}

Transformasi glukosa menjadi HMF tentu saja dipengaruhi oleh jenis garam logam dan waktu reaksi yang digunakan. Jenis garam logam dapat mempengaruhi keasaman Lewis dari ion logam yang digunakan (Zhou et al., 2016). Ni-zeolit memberikan hasil yang paling tinggi dibandingkan Mn dan Cr-zeolit dengan waktu reaksi 6 jam (Tabel 5). Hal ini dapat disebabkan oleh Ni merupakan logam transisi periode awal yang cukup labil karena memiliki elektron pada orbital d yang hampir penuh sehingga cenderung reaktif dalam membantu proses transformasi ini.

Tabel 5. Data rendemen HMF dengan katalis zeolit termodifikasi

\begin{tabular}{lccc}
\hline Katalis & Waktu (Jam) & Suhu $\left({ }^{\circ} \mathrm{C}\right)$ & Rendemen $(\%)$ \\
\hline Cr-zeolit & 6 & 180 & 32,78 \\
Mn-zeolit & 6 & 180 & 35,17 \\
Ni-zeolit & 6 & 180 & 38,68 \\
\hline
\end{tabular}

Logam $\mathrm{Co}$ dan $\mathrm{Cu}$ juga memiliki aktivitas katalitik dalam membantu proses transformasi ini, karena kedua logam ini juga menyediakan orbital kosong yang memfasilitasi terjadinya transfer elektron pada proses isomerisasi glukosa. Namun, kondisi reaksi yang digunakan untuk transformasi, seperti suhu dan tekanan, kurang sesuai sehingga hanya menghasilkan rendemen HMF tidak lebih dari 15\%. Pada penelitian lain, logam kobalt memang lebih baik digunakan sbagai katalis untuk hidrogenolisis HMF menjadi turunannya, DMF (Wang et al., 2019). Oleh karena itu, baik H-zeolit maupun zeolit diembankan logam, mampu mengatalisis transformasi glukosa menjadi HMF. Transformasi glukosa menjadi HMF ini mampu menaikkan fungsi zeolit alam sebagai katalis dan menjadi salah satu alternatif dari penggunaan zeolit pascaadsorpsi logam.

\section{KESIMPULAN}

Zeolit alam Ende NTT teraktivasi asam maupun setelah modifikasi dengan logam memiliki aktivitas katilitik dalam transformasi glukosa menjadi HMF. Semakin banyak 
jumlah logam yang diembankan dalam zeolit akan menurunkan aktivitas katalitiknya. Aktivitas katalitik Ni-zeolit dan Mn-zeolit lebih tinggi dari katalis lain dengan rendemen masing-masing 38,68 dan 35,17\%, meskipun optimasi waktu reaksi masih diperlukan untuk menghasilkan HMF dengan rendemen yang lebih besar.

\section{DAFTAR PUSTAKA}

Assary, R.S., Kim, T., Low, J.J., Greeley, J., Curtiss, L.A., 2012. Glucose and Fructose to Platform Chemicals: Understanding The Thermodynamic Landscapes to Acid Catalyzed Reaction using High Level Ab-Initio Methods. Physical Chemistry Chemical Physics 14, 16603-16611. doi: 10.1039/c2cp41842h.

Aylak, A.R., Akmaz, S., Koc, S.N., 2016. An Efficient Heterogeneous CrOx-Y Zeolite Catalyst for Glucose to HMF Conversion in Ionic Liquids. Particulate Science and Technology 35, 1-17. doi: 10.1080/02726351.2016.1168895.

Covarrubias, C., Garcia, R., Arriagada, R., Yanez, J., Garland, M.T., 2006. Cr(III) Exchange on Zeolites Obtained from Kaolin and Natural Mordenite. Microporous and Mesoporous Materials 88, 220-231. doi: 10.1016/j.micromeso.2005.09.007.

Eminov, S., Filippousi, P., Brandt, A., Ely, J.D.E.T.W., Hallett, J.P., 2016. Direct Catalytic Conversion of Cellulose to 5-Hydroxymethylfurfural using Ionic Liquids. Inorganics 32, 1-15. doi: 10.3390/inorganics4040032.

Guerriero, G., Hausman, J.F., Strauss, J., Ertan, H., Siddiqui, K.S., 2016. Lignocellulosic Biomass: Biosynthesis, Degradation, and Industrial Utilization. Engineering In Life Sciences 16, 1-16. doi: 10.1002/elsc.201400196.

Hattori, H., and Onno, Y., 2015. Solid Acid Catalysis: From Fundamentals to Application. Pan Stanford Publishing Pte. Ltd., Singapura.

Huang, Y.B., and Fu, Y., 2013. Hydrolysis of Cellulose to Glucose by Solid Acid Catalysts. Green Chemistry 15, 1095-1111. doi: 10.1039/c3gc40136g.

Jae, J., Tompsett, G.A., Foster, A.J., Hammond, K.D., Auerbach, S.M., Lobo, R.F., and Huber, G.W., 2011. Investigation into The Shape Selectivity of Zeolite Catalysts for Biomass Conversion. Journal of Catalysis 279, 257-268. doi:10.1016/j.jcat.2011.01.01.

Li, H., Saravanamurugan, S., Yang, S., and Riisager A., 2014. Direct Transformation of Carbohydrates to The Biofuel 5-Ethoxymethylfurfural by Solid Acid Catalysts. Green Chemistry 18, 1-8. doi: 10.1039/x0xx00000x.

Nikolla, E., Leshkov, Y.R., Moliner, M., and Davis, M.E., 2011. “One-Pot” Synthesis of 5(Hydroxymethyl)furfural from Carbohydrates using Tin-Beta Zeolite. ACS Catalysis 1, 408-410. doi: 10.1021/cs2000544.

Ngapa, Y.D., Sugiarti, S., and Abidin, Z., 2016. Hydrothermal Transformation of Natural Zeolite from Ende-NTT and Its Application as Adsorbent of Cationic Dye. Indonesia Journal of Chemistry 16, 138-143. doi: 10.22146/ijc.1091.

Nurhadi, M., Trisunarya, W., Yahya, M.U., Setiadji, B., 2001. Characterization And Modification Of Natural Zeolite And Its Cracking Properties On Petroleum Fraction. Indonesia Journal of Chemistry 1, 7-10. ISSN: 9772460-157006. 
Octaviani, S., Krisnandi, Y.K., Abdullah, I., Sihombing, R., 2013. The Effect of Alkaline Treatment to the Structure of ZSM5 Zeolites. MAKARA of Science Series 16, 155162. doi: 10.7454/mss.v16i3.1476.

Pierella, L.B., Saux, C., Caglieri, S.C., Bertorello, H.R., and Bercoff, P.G., 2008. Catalytic Activity and Magnetic Properties of Co-ZSM-5 Zeolites Prepeared by Different Methods. Applied Catalysis A: General 347, 55-61. doi: 10.1016/j.apcata.2008.05.033.

Putten, R.J.V., Waal, J.C.V.D., Jong, E.D., Rasrendra, C.B., Heeres, H.J., and Vries, J.G.D., 2013. Hydroxymethylfurfural, A Versatile Platform Chemical Made from Renewable Resources. Chemical Reviews 113, 1499-1597. doi: $10.1021 / \mathrm{cr} 300182 \mathrm{k}$.

Qian, X., 2011. Mechanism and Energetics for Acid-Catalyzed $\beta$-D-Glucose Conversion to 5-Hydroxymethylfurfural. Journal of Physical Chemistry A 115, 11740-11748. doi: 10.1021/jp2041982.

Roman-Leshkov, Y., Moliner, M., Labinnger, J.A., and Davis, M.E., 2010. Mechanism of Glucose Isomerization using A Solid Lewis Acid Catalyst in Water. Communications 49, 8954-8957. doi: 10.1002/anie.201004689.

Rosatella, A.A., Simeonov, S.P., Frade, R.F.M., and Afonso, A.M., 2011. 5Hydroxymethylfurfural (HMF) as a Building Block Platform: Biological Properties, Synthesis and Synthetic Applications. Green Chemistry 13, 754-793. doi: 10.1039/c0gc00401d.

Salam, O.E.A., Reiad, N.A., Elshafei, M.M., 2011. A Study of The Removal Characteristics of Heavy Metals from Wastewaters by Low-Cost Adsorbents. Journal of Advanced Research 2, 297-303. doi:10.1016/j.jare.2011.01.008.

Silaghi, M.C., Chizallet, C., Sauer, J., and Raybaud, P., 2016. Dealumination Mechanisms of Zeolites and Extra-Framework Aluminum Confinement. Journal of Catalysis 339, 242-255. doi: 10.1016/j.jcat.2016.04.021.

Tong, X., Ma, Y., and Li, Y., 2010. Biomass into Chemicals: Conversion of Sugars to Furan Derivatives by Catalytic Processess. Applied Catalysis A: General 385, 1-13. doi: 10.1016/j.apcata.2010.06.049.

Trisunaryanti, W., 2016. Material Katalis dan Karakternya. Gadjah Mada University Press, Yogyakarta.

Uddin, M.K., 2016. A Review on The Adsorption of Heavy Metals by Clay Minerals, with Special Focus on The Past Decade. Chemical Engineering Journal 308, 438-462. doi: 10.1016/j.cej.2016.09.029.

Villa, A., Schiavoni, M., Fulvio, P.F., Mahurin, S.M., Dai, S., Mayes, R.T., Veith, G.M., and Prati, L., 2013. Phosphorylated Mesoporous Carbon as Effective Catalyst for The Selective Fructose Dehydration to HMF. Journal of Energy Chemistry 22, 305-311. doi: 10.1016/S2095-4956(13)60037-6.

Wang, X., Liang, X., Li, J., Li, Q., 2019. Catalytic Hydrogenolysis of Biomass-Derived 5hydroxymethylfurfural to Biofuel 2,5-dimethylfuran. Applied Catalysis A: General 576, 85-95. doi: 10.1016/j.apcata.2019.03.005. 
Warner, T.E., Klokker, M.G., and Nielsen, U.G., 2017. Synthesis and Characterization of Zeolit $\mathrm{Na}-\mathrm{Y}$ and Its Conversion to The Solid Acid Zeolite H-Y. Journal of Chemical Education 94, 781-785. doi: 10.1021/acs.jchemed.6b00718.

Yu, I.K.M., and Tsang, D.C.W., 2017. Conversion of Biomass to Hydroxymethylfurfural: A Review of Catalytic System and Underlying Mechanism. Biosource Technology 238, 716-732. doi: 10.1016/j.biortech.2017.04.026.

Zhou, C., Zhao, J., and Yagoub, A.E.G.A., Ma, H., Yu, X., Hu, J., Bao, X., and Liu, S., 2016. Conversion of Glucose into 5-hydroxymethylfurfural in Different Solvents and Catalysts: Reaction Kinetics and Mechanism. Egyptian Journal of Petroleum 26, 477-487. doi: 10.1016/j.ejpe.2016.07.005. 